\title{
“Também eram exploradas!": as mulheres e o Primeiro de Maio em Manaus na década de 1910
}

\author{
"They were also explored!": women and the May Day in Manaus \\ in the 1910's
}

\section{Richard Kennedy Nascimento Candido*}

\begin{abstract}
Resumo: Neste artigo, temos como objetivo demostrar como as mulheres trabalhadoras da cidade de Manaus participaram das mobilizações do Primeiro de Maio durante a década de 1910. Enfocaremos na trajetória das trabalhadoras da Fábrica de Roupas Amazonense, que empreenderam sucessivas greves na cidade entre 1911 e 1913. A partir da imprensa manauara - tanto jornais operários quanto jornais da chamada grande imprensa -, observamos a participação delas no préstito de 1914 quando foram convidadas a seguir o cortejo. A atuação da imprensa também foi alvo de análise neste artigo, principalmente quando os diversos jornais observados escreveriam de forma distinta acerca da participação dessas mulheres. Contudo, apesar do Primeiro de Maio ser encarado como um tema clássico na historiografia, ele ainda pode ser alvo de novas análises, sobretudo a partir de novas perguntas e abordagens das fontes.
\end{abstract}

Palavras-Chave: Primeiro de Maio; mulheres; Manaus.

\begin{abstract}
The article aims to demonstrate how the working women of Manaus City participated of the mobilizations of the May Day trough the 1910 decade. Focusing in the trajectory of the workinkg women of the Fabrica Amazonense de Roupas who undertook successive strikes in the city between 1911 and 1913. From the Manauara press - both worker's newspapers and newspapers of the so-called big press - we observed their participation in 1914 when they were invited to follow the procession. The performance of the press was also analyzed in this article, especially when the various newspapers observed would write differently about their
\end{abstract}

* Doutorando em História pela Universidade Federal do Amazonas (UFAM). ORCID: https://orcid.org/00000002-3719-1897. E-mail: richard_lp13@hotmail.com. 
participation. However, although May 1 is regarded as a classic theme in historiography, it can still be the subject of further analysis, especially from new questions and approaches from the historical sources.

Keywords: May Day; Woman; Manaus.

\section{Introdução}

Se bem que o $1^{\circ}$ de Maio não fosse o que deveria ser, não é menos verdade de que ele assinalou uma página homérica na história do Trabalho no Amazonas. ${ }^{1}$

OMO RESSALTOU DIDO, pseudônimo do autor do trecho desta nota do jornal A Lucta Social, a mobilização do Dia do Trabalhador do ano de 1914 em Manaus seria marcante. Neste dia, as trabalhadoras da Fábrica de Roupas Amazonense participaram de forma ativa das mobilizações do Primeiro de Maio na cidade, sobretudo quando o préstito fez uma parada em frente ao estabelecimento fabril em que elas trabalhavam.

A mobilização caminhava em direção à rua da Instalação e parou em frente à fábrica para saudar as trabalhadoras. Segundo a nota do jornal, o préstito era pacífico e silencioso no qual só ouviam-se as "pisadas dos homens de trabalho". ${ }^{2}$ Nessa movimentação, as operárias foram caracterizadas como cristãs que receberiam Jesus (os operários masculinos), em que era possível rememorar uma das mais diversas passagens bíblicas.

A operária Cecília Miranda foi escolhida como representante das outras trabalhadoras para proferir um discurso no qual, segundo o autor da nota do jornal, apresentou a solidariedade da classe aos operários homens que já estavam participando da mobilização. Na sequência, ao final da fala de um acadêmico da Universidade Livre de Manaós, as operárias da fábrica foram convidadas para acompanhar o cortejo junto aos outros trabalhadores que estavam indo em direção ao teatro Alcazar.

Essa mobilização de 1914, vista pela ótica do jornal anarquista A Lucta Social, nos apresentou um viés pouco explorado: a participação das mulheres trabalhadoras nas comemorações do Primeiro de Maio. Essas operárias serão importantes para entendermos as relações de gênero dentro de um tema considerado clássico pela historiografia do trabalho, a partir da cidade de Manaus, no norte do país.

Analisaremos aqui as experiências das mulheres e suas vivências e relações com o Primeiro de Maio. Traremos o exemplo da Fábrica de Roupas Amazonense por ter sido uma das poucas fábricas onde as trabalhadoras se envolveram diretamente com o Dia do Trabalhador. Sua história foi pouco explorada pela historiografia amazonense e sua importância

1 A Lucta Social, Manaus, p. 4-6, 1 jun. 1914.

2 A Lucta Social, Manaus, p. 4-6, 1 jun. 1914. 
só foi possível de ser mensurada a partir da grande quantidade de informações recolhidas exclusivamente nos veículos de imprensa.

Sendo assim, buscou-se mapear a presença das mulheres trabalhadoras nas mobilizações do Primeiro de Maio na cidade de Manaus a partir da leitura de três jornais: Jornal do Comércio, A Lucta Social, de Manaus, e A Voz do Trabalhador, do Rio de Janeiro, todos de 1914. Para que se chegasse nesses números, foram analisadas diversas edições de jornais da imprensa manauara nas datas próximas ao dia $1^{\circ}$, com o objetivo de entender melhor quem eram essas trabalhadoras que participavam dos préstitos, assim como suas lutas e vivências.

\section{Uma breve história do Primeiro de Maio}

ENCARADA COMO UMA DATA TRADICIONAL dentro dos estudos do trabalho no mundo inteiro, o Primeiro de Maio ganhou análises de diversos historiadores e historiadoras. Caracterizada como "o nascimento de um rito operário" por Michelle Perrot ${ }^{3}$ ou como "o nascimento de um feriado" por Eric Hobsbawm, o Primeiro de Maio assinalava-se como uma data criada a partir e para os próprios operários e operárias. ${ }^{4}$ Para Hobsbawm, foi uma das primeiras celebrações instauradas por um movimento extraoficial de homens e mulheres pobres. ${ }^{5}$

Eric Hobsbawm destacou também que o ritual público do Primeiro de Maio "cada vez mais tendia a ser uma espécie de teatro público, no qual a distinção entre participantes e expectadores, atores e coadjuvantes, atenuava-se e onde a própria massa atuava como seu próprio símbolo". ${ }^{6}$ Foi dessa maneira que foram sendo incorporados em seus préstitos vários elementos cuja ritualística é importantíssima de se analisar, como por exemplo, a presença massiva de estandartes das associações operárias.

No Brasil, Claudio Batalha caracterizou o Primeiro de Maio como a data mais importante da cultura associativa. ${ }^{7}$ Sua grandiosidade foi observada de maneira mais efetiva quando as instituições operárias começaram a se consolidar no Brasil. Batalha assinalava que o crescimento do Primeiro de Maio foi intimamente ligado ao processo de organização da classe trabalhadora, sobretudo a partir do século XX.

Como uma data que se tornou grandiosa já nos primeiros anos, foi possível perceber também mudanças significativas ao longo do tempo, sobretudo entre a Primeira República e

3 PERROT, Michelle. Os excluídos da História: operários, mulheres e prisioneiros. $7^{\text {a }}$ ed. Rio de Janeiro/São Paulo: Paz e Terra, 2017.

4 HOBSBAWM, Eric J. O nascimento de um feriado: o Primeiro de Maio. In: HOBSBAWM, Eric J. Pessoas extraordinárias: resistência, rebelião e jazz. Tradução de Irene Hirsch e Lólio Lourenço de Oliveira. São Paulo: Paz e Terra, 1998.

5 HOBSBAWM, Eric J. El nacimiento de una fiesta: el Primero de Mayo. PERRERAC. Disponível em: https:// pt.scribd.com/document/346962987/Eric-Hobsbawm-El-Nacimiento-de-Una-Fiesta-El-Primero-de-Mayo. Acesso em: 1 jun. 2020.

6 HOBSBAWM, Eric J. Mundos do Trabalho: novos estudos sobre a História Operária. 6ª ed. São Paulo: Paz e Terra, 2015, p. 133.

7 Por cultura associativa, Batalha entende "um conjunto de valores compartilhados pelas associações operárias". Ver mais: BATALHA, Claudio Henrique de Moraes. Cultura associativa no Rio de Janeiro da Primeira República. In: BATALHA, Claudio Henrique de Moraes; SILVA, Fernando Teixeira da; FORTES, Alexandre (org.). Culturas de classe: identidade e diversidade na formação do operariado. Campinas: Editora da Unicamp, 2004, p. 105. 
o Estado Novo. Lindercy Lins observou para o estado do Ceará, uma das primeiras reflexões sobre a data fora do eixo centro-sul, as relações da Igreja Católica com os rituais do Dia do Trabalhador. ${ }^{8}$ Para ele, essas relações eram fruto de uma constante consolidação das mobilizações na região, assumindo, assim, caráter religioso-festivo que foi propagado pelos Círculos Operários Católicos. ${ }^{9}$

Debruçando-se mais sobre os anos 1930, Isabel Bilhão ponderou umas das pautas mais importantes que versavam sobre o Primeiro de Maio em "Trabalhadores no Brasil!: as comemorações do Primeiro de Maio em tempos de Estado Novo varguista". A autora observou um ponto em comum nas análises sobre a data tanto durante a Primeira República quanto durante o Estado Novo: as sistemáticas tentativas de apropriação da data que acabavam por reafirmar o grande potencial do Dia do Trabalhador. ${ }^{10}$ Segundo a autora, as concentrações das mobilizações:

Foram apresentadas como 'movimento cívico-trabalhista', 'comício cívicomilitar' e como 'ato cívico-artístico-desportivo'. Embora variando na ênfase, tiveram em comum a combinação de diversões populares com exaltação cívico-nacionalista e do governo, bem como a busca permanente da normatização e controle da presença e da participação do público, a quem o papel destinado seria o de espectador. ${ }^{11}$

O Primeiro de Maio até os dias atuais sofre dessas tentativas de apropriação da data, sobretudo pelos segmentos patronais e/ou pelo próprio Estado. Tanto o patronato quanto o Estado mantêm sistemáticas e duradouras formas de se apropriar sobre a data nos mais diversos períodos históricos, como no Estado Novo e na ditadura militar. ${ }^{12}$

Contudo, a história do Primeiro de Maio no Brasil pode ser observada a partir de disputas que envolviam dois grupos de trabalhadores durante a Primeira República: socialistas e anarquistas. Os anarquistas buscavam suas origens em Chicago, em 1886, quando no Primeiro de Maio ocorreu a deflagração de diversas greves por todo o país.

A polícia passou a reprimir os manifestantes e no dia 3 de maio atacou uma reunião em que um grupo de trabalhadores debatia a massiva demissão de pelo menos dois mil operários na fábrica McCormick. O resultado do ataque foi de quatro mortos e dezenas de feridos. No dia seguinte, na praça Haymarket houve mais protestos que se incorporaram à insatisfação com as mortes do dia anterior.

8 Devemos destacar que as relações entre os rituais católicos e o Primeiro de Maio no Amazonas ainda carecem de análises mais aprofundadas.

9 LINS, Lindercy Francisco Tomé de Souza. Um dia, muitas histórias... Trajetória e concepções do Primeiro de Maio em Fortaleza da Primeira República ao Estado Novo. Dissertação (Mestrado em História) - Universidade Federal do Ceará, Fortaleza, 2006, p. 91.

10 BILHÃO, Isabel. Trabalhadores do Brasil!: as comemorações do Primeiro de Maio em tempos de Estado Novo varguista. Revista Brasileira de História. São Paulo, v. 31, n. 62, 2011, p. 89.

11 Ibidem, p. 90.

12 CANDIDO, Richard Kennedy Nascimento. Primeiro de Maio em tempos de repressão: o "Grande Dia" do operariado mundial na ditadura civil-militar brasileira, através do Jornal do Comércio do Amazonas (19641968). Revista Manduarisawa. v. 1, n. 1, 2017, p. 98-112. 
A mobilização era intercalada aos discursos das diversas lideranças, entre eles August Spies, Albert Parsons e Samuel Fielden. A polícia já cercava a mobilização quando uma bomba foi arremessada contra eles, ocasionando o ferimento de vários policiais, além da morte de um deles. A partir disso, os policiais repreenderam novamente os trabalhadores e os culparam pelo fato ocorrido. ${ }^{13}$ Dessa vez, o número de mortos foi muito elevado, assim como o de feridos.

$\mathrm{Na}$ sangrenta praça Haymarket houve grande número de vítimas e as autoridades detiveram os dirigentes operários.

À procura do culpado pelo arremesso da bomba, seguiram-se meses de perseguição indiscriminada a líderes sindicais. Sem encontrar o responsável, a polícia deu ordem de prisão a dirigentes anarquistas: Fisher, Parsons, Engel, Spies, Lingg, Neeb, Schwab, Fielden, Lessinger e Most. ${ }^{14}$

Os protestos contra as jornadas de trabalho extenuantes passaram a ser também, a partir desse momento, contra a punição aos trabalhadores que estavam sendo acusados de plantar a bomba. O Tribunal de Justiça reconsiderou o julgamento de alguns operários por não haver provas suficientes, entretanto alguns outros militantes já haviam perdido a vida pelos enforcamentos condenatórios. ${ }^{15}$

Embora reprimidos, os trabalhadores conseguiram as oito horas de labuta em diversos estados norte-americanos. Mesmo com a vitória parcial, era necessário conquistar a redução em todo o território estadunidense, bem como incentivar, aos outros operários, da importância da luta pela melhoria das condições de trabalho. ${ }^{16}$

Já os socialistas remetiam as origens da data ao Congresso Internacional de Paris, realizado em 1889. A historiadora Michelle Perrot nos mostrou que o objetivo dos trabalhadores presentes na Internacional de 1889 era "dar à classe operária consciência de si mesma através da realização de gestos idênticos num amplo espaço e de impressionar a opinião pública com tal espetáculo". ${ }^{17}$ Ou seja, fazer com que os trabalhadores e trabalhadoras do mundo todo se reunissem em um mesmo horário e lutassem pelas mesmas pautas para que chamassem a atenção da sociedade e mostrassem que a classe era unida, caracterizando-se assim como uma data de cunho internacional.

A luta pelas oito horas diárias foi o cerne que moveu as primeiras manifestações que marcaram as lutas de toda a classe, ainda no século XIX e início do século XX. Com efeito, em muitos casos, a jornada chegava a ser de 17 horas por dia, não existindo condições de trabalho adequadas a gênero ou faixa etária, assim como outros direitos fundamentais na atual configuração da legislação trabalhista: férias, descanso semanal e muito menos

13 FONTANA, Hugo. Haymarket, Chicago, $1^{\circ}$ maio 1886. Verve, n. 27, 2015, p. 13-28.

14 CARDOSO, Alcina de Lara e ARAÚJO, Silvia Pereira de. $1^{\circ}$ de Maio: cem anos de solidariedade e luta. Curitiba: Beija-Flor, 1986, p. 13-14.

15 LINS, op. cit., p. 31.

16 Ibidem.

17 PERROT, op. cit., p. 129-130. 
aposentadoria. Lutava-se para chegar ao ideal de oito horas de trabalho, oito horas de descanso e oito horas de lazer.

Essa era uma situação dramática que se arrastava desde os primórdios da Revolução Industrial e que logo cedo chamou a atenção do pensamento social, que passou a denunciála. ${ }^{18}$ Muitos desses operários mesmo doentes sacrificavam-se nas indústrias para não perder o emprego que, apesar da exploração, era fonte que sustentava toda a família. Não havia nenhuma legislação protetiva, tendo esta surgida, muito lentamente, a partir de 1917, em clara relação com a luta operária. ${ }^{19}$

As disputas pelas origens da data construíram a ideia dos "Mártires de Chicago" que permaneceu por bastante tempo no imaginário da classe trabalhadora. Claudio Batalha destacou que essa ideia foi ligada a uma questão de "redenção" e "desse modo se opera uma transformação do Primeiro de Maio, tornado celebração da morte e da redenção final. Como Cristo, os Mártires de Chicago e todos aqueles que tombam na luta contra a burguesia dão seu sangue pelo proletariado". ${ }^{20}$

$\mathrm{Na}$ cidade de Manaus, os jornais locais também exemplificavam a rememoração aos "Mártires de Chicago" ao noticiar que as mobilizações iniciavam-se a partir do cemitério São João Batista e partiam em direção a locais que os próprios trabalhadores consideravam ser importantes. $^{21}$

A ida aos cemitérios "em respeito à memória dos operários mortos, como forma de homenagear sua trajetória"22 não era algo exclusivo de Manaus. Desde os primórdios da data, no mundo inteiro, era corriqueiro que isso ocorresse nesse dia, transformando-se, assim, em um rito consagrado da classe trabalhadora. Essas visitas ao cemitério não eram aleatórias e nem eram motivo de desmobilização dos trabalhadores. Lindercy Lins apontou que funcionava como um "motivador da luta" dos trabalhadores fazendo reavivar as lembranças dos mártires de Chicago a partir dos mártires locais. ${ }^{23}$

Os mártires locais foram difundidos também a partir das próprias lideranças locais. Luciano Teles evidenciou como as redes de contato entre os trabalhadores locais e nacionais influenciaram grandes acontecimentos na cidade, inclusive o Primeiro de Maio. ${ }^{24}$ Destacamos a importância de algumas lideranças locais como Joaquim Azpilicueta, Tércio de Miranda, Cursino da Gama, entre outros, ligadas a grupos socialistas e anarquistas da cidade e com uma vasta literatura na historiografia do trabalho da cidade. ${ }^{25}$

18 ENGELS, Frederich. A situação da classe trabalhadora na Inglaterra. São Paulo: Global, 1985.

19 GOMES, Angela de Castro Gomes. Cidadania e direitos do trabalho. Rio de Janeiro: Jorge Zahar Editor, 2002.

20 BATALHA, op. cit., p. 109

21 Jornal do Comércio do Amazonas, Manaus, p. 2, 27 abr. 1925.

22 LINS, op. cit., p. 78.

23 Ibidem, p. 82.

24 TELES, Luciano Everton Costa. Construindo redes sociais, projetos de identidade e espaços políticos: a imprensa operária no Amazonas. Tese (Doutorado em História) - Instituto de Filosofia e Ciências Humanas, Universidade Federal do Rio Grande do Sul, Porto Alegre, 2018.

25 TELES, Luciano Everton Costa. Mundos do Trabalho no Amazonas: as lideranças operárias socialistas Joaquim Azpilicueta, Nicodemos Pacheco, Manoel Sérvulo e Cursino da Gama (1914-1928). Antítese, v. 11, 
O Primeiro de Maio em Manaus era articulado, assim como Batalha havia assinalado, junto aos avanços do processo associativo, das mobilizações e das greves. Contudo, as disputas internas entre anarquistas e socialistas em torno das origens do Primeiro de Maio também movimentavam as ações em Manaus, sobretudo entre essas duas correntes. ${ }^{26}$ Tanto nos discursos das lideranças quanto nas escolhas das ruas por onde os préstitos passariam durante a data. Com isso, era possível observar o campo de influência dessas lideranças da cidade.

Esses dois grupos também rivalizavam na interpretação sobre esse dia. Militantes socialistas incorporaram a ideia de que a data deveria ser usada como celebração ao trabalho. Era difundido um ideal de confraternização geral entre todas as classes laborais e que, por vezes, setores patronais e o Estado estavam alinhados. ${ }^{27}$ Os anarquistas viam a data como um dia de luta e eram avessos às ideias festivas. Alguns militantes alegavam que "ao comemorar com festas o $1^{\circ}$ de maio, o operariado estava, na realidade, colaborando com seus inimigos". Outros militantes caracterizavam essa festa como um desvio de sentido da data e um desrespeito à memória dos mortos. ${ }^{28}$

O jornal manauara A Lucta Social, o mais ferrenho defensor de um Primeiro de Maio combativo, publicou um artigo escrito por Anselmo Lorenzo chamado ironicamente de " $A$ Festa do Trabalho". Irônico porque ele inicia falando que "as festas se realizam para celebrar ou comemorar um triunfo" e que "o trabalho, esse, ainda não triunfou". De forma objetiva, o autor da nota se mostrou inquieto com a possibilidade de um Primeiro de Maio festivo e se questionou:

Poderá o trabalhador embelezar com frescas e aromáticas flores a máquina em que se extenua para ganhar uma ridicularia que mal chega para o pão e caldo, a oficina que o sufoca, as cadeias que cortam a liberdade, o chicote que o açoita, a organização social contemporânea que pretende reduzi-lo à submissão e à impotência? ${ }^{29}$

Esse questionamento não se esgotou nessas palavras. O autor do artigo comparou o festejo do Primeiro de Maio à Páscoa, acusando os socialistas reformistas de implantar essa ideia de triunfo, que segundo os anarquistas, ainda não havia acontecido. Anselmo Lorenzo destacou que "o nosso trabalho que é duro e insuportável, extenuante e doloroso, ainda não triunfou".

n. 21, 2018, p. 430-460.

26 TELES, Luciano Everton Costa. Imprensa e Mundos do Trabalho: a singularidade da imprensa operária no Amazonas. Revista Mundos do Trabalho, v. 3, n. 5, 2011, p. 210.

27 ARÊAS, Luciana Barbosa. A redenção dos operários: o Primeiro de Maio no Rio de Janeiro durante a República Velha. Dissertação (mestrado em História) - Instituto de Filosofia e Ciências Humanas, Universidade Estadual de Campinas, Campinas, 1996, p. 117.

28 Ibidem, p. 121.

29 A Lucta Social, Manaus, p. 2, 1 maio 1914. 


\title{
"Vai fechar a Fábrica de Roupas Amazonense: a atitude das operárias"
}

\begin{abstract}
Em passada edição desta folha, publicamos uma local, noticiando o fato de ter a firma proprietária da Fábrica de Roupas Amazonense solicitado da Manaós Tramways and Light Co. Limited um abatimento nas despesas de energia elétrica, prometendo fechar o seu estabelecimento caso não fosse atendida.
\end{abstract}

O prazo marcado pela referida firma para a espera da resolução da companhia terminou ontem, razão porque os srs. Cunha e Cia. fizeram anunciar que fecharão amanhã as portas da fábrica.

Por esse motivo, as operárias respectivas fizeram distribuir profusamente pela cidade o seguinte boletim:

"Acabamos de saber que, em vista da teimosia da Companhia da Luz, não atendendo ao pedido de abatimento sobre o preço da energia elétrica que se gasta na fábrica, estamos sem serviço de segunda-feira em diante, por ter a firma proprietária resolvido assim proceder devido às enormes dificuldades com que vem lutando para dar-nos pão e trabalho.

E como, conosco ficam a sofrer as torturas da fome perto de trezentas pessoas de nossas famílias, a quem sustentamos com os esforços de nossos labores, apelamos para todas as classes sociais de Manaus, afim de que sejam solidárias conosco na defesa dos nossos interesses. - Manaus, 16 de agosto de 1913. - A comissão - Maria Coelho, Santina de Jesus, Maria da Silva Jatahy, Rosa Del Aguila, Posidonia Coelho, Rosa Lima."

\section{$[\ldots]$}

As operárias, soube a nossa reportagem, reuniram-se ontem à noite na residência da diretoria das mesmas, que é a primeira signatária do boletim, e deliberaram manter-se unidas na defesa de suas causas, procurando para auxiliá-las os elementos que algumas vezes têm estado ao seu lado, especialmente a imprensa local.

A comissão de operárias estará reunida todos os dias, pela manhã e à tarde, na própria fábrica, por gentileza do gerente da mesma. ${ }^{30}$

EM 17 dE AGosto DE 1913, o Jornal do Comércio divulgou extensa nota alertando a sociedade do que ocorria na Fábrica de Roupas Amazonense. O título da nota avisava que a fábrica iria fechar e as operárias tomaram a decisão de criar uma comissão para tentar resguardar seus empregos. Mas qual o motivo do fechamento da fábrica? Maria Luiza Ugarte Pinheiro apontou que a fábrica não tinha recursos para pagar a empresa de luz elétrica Manaós Tramways and Lights, e que por isso havia ameaçado cortar seu fornecimento à empresa. ${ }^{31}$

A despesa com a energia elétrica chegou a 700 mil réis por mês. ${ }^{32}$ Os donos da fábrica anunciaram seu fechamento e uma comissão de funcionárias foi criada para tentar

30 Jornal do Comércio do Amazonas, Manaus, p. 2, 17 ago. 1913

31 PINHEIRO, Luís Balkar Sá Peixoto e PINHEIRO, Maria Luiza Ugarte. Mundos do Trabalho na cidade da borracha: trabalhadores, lideranças, associações e greves operárias em Manaus (1880-1930). Jundiaí: Paco Editorial, 2017, p. 164.

32 PRAIA, Benta Litaiff. Dimensões do trabalho feminino: outras imagens da Manaus da borracha (1910-1930). In: PINHEIRO, Maria Luiza Ugarte (org.). Gênero \& imprensa na história do Amazonas. Manaus: EDUA, 2014, p. 75. 
resolver esse imbróglio. Segundo a historiadora Benta Littaif Praia, "as operárias tornaram-se vulneráveis à manipulação paternalista" para que saíssem em defesa do empreendimento, "principalmente porque os salários complementavam a subsistência". ${ }^{33}$ Muito embora, sabemos que as operárias tinham consciência e usavam dessa estratégia para resguardar seus empregos e definitivamente atuavam como agentes de sua própria história.

$\mathrm{Na}$ verdade, nem todas as mulheres usavam seus salários para complementação de renda, pois algumas eram chefas de família e responsáveis por manter toda a estrutura familiar - tanto que uma das operárias, chamada de $A$, foi nota num jornal de humor, onde dizia em tom jocoso "que no Beco do Pau Não Cessa (Tecos), tem uma certa A que trabalha na Fábrica de Roupas que não pode deixar de trabalhar (diz que), senão morre de fome", ${ }^{34}$, mas, corroborando com essa necessidade das trabalhadoras de manterem seus empregos e de sua dependência ao dinheiro fruto de seu trabalho.

Cláudia Fonseca destacou que mesmo quando eram casados, "nem todos os homens se preocupavam com o sustento da casa", ficando com as mulheres a árdua tarefa de sua manutenção. Nas suas análises para o Rio Grande do Sul, a autora observou que, em muitos casos, as mulheres eram as principais provedoras da família, mas que suas ações eram sempre colocadas "como um mero suplemento à renda masculina". ${ }^{35}$

Como mostrou Chitra Joshi, o conceito do homem provedor invisibilizava as formas pelas quais as mulheres da classe trabalhadora mantiveram suas famílias, além desse conceito ter pouca significação em momentos nos quais os homens estavam cada vez mais desempregados. ${ }^{36}$ Isabelle Pires, em dissertação de mestrado, mostrou que muitas mulheres exerciam papel de protagonistas nas suas famílias com seus rendimentos, que apesar de serem menores que os dos homens, mesmo assim ainda servia para sustentar a si e seus dependentes. ${ }^{37}$

Curioso observar que as reuniões da comissão criada pelas operárias ocorriam na própria sede da fábrica "por gentileza do gerente". Essa relação entre gerente e operárias gerou comentários sobre manipulações paternalistas em uma ação vinda de cima para baixo. ${ }^{38}$ Pinheiro, entretanto, questionou essa visão alegando que "as operárias agiram de comum acordo e de forma independente na mobilização empreendida", 39 destacando que tinham objetivos próprios como lutar contra a fome. ${ }^{40}$

33 PRAIA, op. cit., p. 79.

34 O Chicote, Manaus, p. 1, 1 nov. 1913.

35 FONSECA, Cláudia. Ser mulher, mãe e pobre. In: PRIORE, Mary Del (org.). História das mulheres no Brasil. São Paulo: Contexto, 1997, p. 510-553.

36 JOSHI, Chitra. Além da polêmica do provedor: mulher, trabalho e história do trabalho. Revista Mundos do Trabalho, v. 1, n. 2, 2009, p. 155.

37 PIRES, Isabelle Cristina da Silva. Entre teares e lutas: relações de gênero e questões etárias nas principais fábricas de tecidos do Distrito Federal (1891-1932). Dissertação (mestrado em História, Política e Bens Culturais) - Centro de Pesquisa e Documentação de História Contemporânea do Brasil, Fundação Getúlio Vargas, Rio de Janeiro, 2018, p. 100-101.

38 PRAIA, op. cit., p. 79.

39 PINHEIRO e PINHEIRO, op. cit., p. 165.

40 Jornal do Comércio do Amazonas, Manaus, p. 2, 17 ago. 1913. 
As trabalhadoras pediram apoio de diversas sociedades operárias e da própria imprensa para ajudá-las na difícil tarefa da manutenção de seus empregos. A fábrica fechou por um período, mas as operárias não desistiram de lutar por seus empregos e continuaram fazendo reuniões. Grande parte dos movimentos dos trabalhadores organizados do período as ajudava, entre eles a Associação dos Empregados no Commercio, o Centro Agronômico, a Sociedade das Artes Graphicas e a União Acadêmica. Numa das reuniões na sede da Associação dos Empregados no Commercio, foi cogitado tratar-se de exploração por parte da firma Cunha e Cia., e que a sociedade de trabalhadores deveria estar ao lado das operárias ao invés de tomar as dores dos exploradores. ${ }^{41}$ Tais palavras de apoio foram recebidas positivamente pelas grevistas.

Nessa greve bem sucedida de 1913, graças a toda a mobilização empreendida pelas mulheres, houve um "acordo estabelecido pela comissão operária com a fábrica e a The Manaós Tramways and Lights" para a fábrica funcionar por mais um ano. ${ }^{42}$ Nesse caso, operárias e patrões tinham o mesmo objetivo, que a fábrica continuasse ativa, mas com motivações muito diversas: enquanto os donos pensavam no futuro de seu empreendimento, as operárias pensavam nos seus empregos, fundamentais para a manutenção de suas famílias.

Contudo, nosso leitor deve se questionar de qual fábrica estamos falando? Qual seu impacto na composição e sua inserção na classe trabalhadora da cidade de Manaus? De proprietários portugueses, a Fábrica de Roupas Amazonense foi inaugurada em outubro de 1910, com ampla divulgação na imprensa local, sendo apresentada como um dos grandes estabelecimentos fabris da cidade de Manaus. ${ }^{43}$ Mesmo antes de sua inauguração, seus proprietários já pediam isenção de impostos estaduais pelo prazo de cinco anos ao congresso local, ${ }^{44}$ para ajudar no estabelecimento da indústria.

As propagandas divulgadas na imprensa manauara afirmavam que aquela era "a mais bem montada no gênero no Brasil, movida pela eletricidade", podendo fornecer até "800 peças por dia, pois temos como mestre uma das primeiras tesouras conhecidas em Portugal", e ofereciam, principalmente, roupas para homens e meninos. ${ }^{45}$ Cabe aqui destacar que a fábrica tinha capacidade para abrigar 70 trabalhadoras, era dividida em três setores com

41 Jornal do Comércio do Amazonas, Manaus, p. 3, 20 ago. 1920.

42 PINHEIRO e PINHEIRO, op. cit., p. 165.

43 A participação e importância dos portugueses no mundo do trabalho da cidade de Manaus vem gradativamente ganhando destaque nos estudos locais. Destacamos os trabalhos de PINHEIRO, Luís Balkar Sá Peixoto. Tensões, disputas e conflitos étnicos na formação do proletariado amazonense: o caso dos portugueses (1890-1930). In: SARGES, Maria de Nazaré; FIGUEIREDO, Aldrin Moura de; AMORIM, Maria Adelina (orgs.) O imenso Portugal: estudos luso-amazônicos. 1ª ed. Belém: UFPA/Cátedra João Lúcio de Azevedo, 2019, p. 549-267. PINHEIRO, Maria Luiza Ugarte. Mulheres portuguesas na belle époque manauara, 1880-1920. In: MENEZES, Lená Medeiros de; SOUZA, Fernando (org.). Brasil - Portugal: pontes sobre o Atlântico, múltiplos olhares sobre a e/imigração. $1^{\text {a }}$ ed. Rio de Janeiro: Eduerj, 2017, v. 1; PINHEIRO, Geraldo. Imprensa, política e etnicidade: portugueses letrados na Amazônia (1885-1933). Tese (Doutorado em História) - Universidade do Porto, Porto, 2012.

44 Jornal do Comércio do Amazonas, Manaus, p. 7, 28 jul. 1910.

45 Jornal Pequeno, Manaus, p. 4, 5 jul. 1911. 
42 máquinas de cortar, costurar e pregar botões ${ }^{46}$ As costureiras eram de maioria portuguesa, ${ }^{47}$ e sua produção era voltada quase que exclusivamente aos homens. ${ }^{48}$

Meses depois, após um de seus sócios sair da direção da fábrica, B. Levy anunciou sua venda nos jornais, apresentando-a como "nova e excelente" e garantindo que todas as suas máquinas eram movidas a eletricidade. O motivo da venda era "por não terem pessoa habilitada que tome conta da mesma". Na falta de um comprador, B. Levy aceitaria até mesmo um sócio com experiência no ramo. ${ }^{49} \mathrm{O}$ fato é que, no dia 15 de janeiro de 1911, a fábrica teria um novo dono, Cunha \& Cia. ${ }^{50}$

Sob nova direção, em maio de 1911, um incêndio no estabelecimento vizinho acometeu a fábrica e acabou por trazer prejuízos severos à oficina, por conta da grande quantidade de água usada para apagar o fogo. O incêndio aconteceu na Casa 103 Velho, que ficou completamente destruída. O fogo teve início por volta da meia-noite, e apesar da falta d'água, os bombeiros conseguiram controlar as chamas cerca de duas horas depois. ${ }^{51}$ Por esses danos, os proprietários da fábrica receberam da Lloyd Americano, um banco de seguros com sede em Manaus, cerca de 2:260\$000 "pelos estragos causados em suas fazendas, pelo incêndio casual que se manifestou no prédio n. 30 , na noite de 4 do corrente". ${ }^{52}$

A Fábrica de Roupas Amazonense passou a aparecer de forma mais sistemática na imprensa a partir de 1911, por conta de uma greve empreendida por suas trabalhadoras. Elas voltaram às páginas dos jornais em outros momentos: além de 1911, devido aos baixos salários recebidos, em 1912, por conta da demissão do gerente, e em 1913, devido ao fechamento do empreendimento.

Nota-se uma grande mobilização dessas trabalhadoras que, em meio a esses eventos, apareciam na imprensa em jornais de fofoca como em A Marreta, ao serem noticiadas como "costureira da fábrica" ou "costureirinhas", sempre sem nome e de forma pejorativa, ${ }^{53}$ por trabalharem fora de seus lares. ${ }^{54} \mathrm{O}$ trabalho feminino na esfera pública colocava a mulher em suspeição e era tido como uma ameaça à ordem natural das coisas, já que tirava a mulher de seus principais papéis de mãe e esposa e, por isso, devendo ser combatido. ${ }^{55} \mathrm{Um}$ manifesto assinado pelo Centro Operário de Manaus, em 1920, alertava as mulheres para que lutassem contra o "feminismo depravado" e que continuassem no "natural determinismo de filha, esposa e mãe". ${ }^{56}$

46 Jornal do Comércio do Amazonas, Manaus, p. 7, 2 out. 1910.

47 PINHEIRO e PINHEIRO, op. cit., p. 163.

48 Jornal Pequeno, Manaus, p. 4, 5 jul. 1911.

49 Jornal do Comércio do Amazonas, Manaus, p. 5, 4 jan. 1911.

50 Jornal do Comércio do Amazonas, Manaus, p. 5, 14 jan. 1911.

51 Jornal do Comércio do Amazonas, Manaus, p. 2, 5 maio 1911.

52 Jornal do Comércio do Amazonas, Manaus, p. 3, 6 maio 1911.

53 A Marreta, Manaus, p. 1, 15 dez. 1912.

54 A Marreta, Manaus, p. 1, 2 fev. 1913.

55 SILVA, Isabel Saraiva. Mulheres impressas: amor, honra e violência no cotidiano das mulheres em Manaus, 1932-1962. Dissertação (Mestrado em História) - Instituto de Ciências Humanas e Letras, Universidade Federal do Amazonas, Manaus, 2016, p. 48.

56 Vida Operária, Manaus, p. 2, 9 maio 1920. 
Contudo, é preciso voltar três anos para que se entenda melhor como se passaram essas greves na cidade e quais foram as suas repercussões na imprensa e na historiografia local, tendo em vista que essas mesmas greves já foram alvo de outras análises, inclusive, tendo sido a de 1911 alçada como uma das primeiras greves femininas empreendidas em Manaus. ${ }^{57}$

A greve de 1911 ocorreu no mês de agosto e "teve como motivação uma redução salarial promovida pelo gerente da fábrica". ${ }^{58}$ Além de atrasar os pagamentos, o gerente efetuou alguns descontos nos salários das operárias. ${ }^{59} \mathrm{Na}$ nota do jornal Correio do Norte, foi destacado que o direito à greve era reconhecido e a greve era assegurada por vários motivos. ${ }^{60}$ No momento de sua deflagração, o Jornal do Comércio noticiou que a fábrica tinha 33 funcionárias. ${ }^{61}$ Infelizmente não foi possível saber como findou essa primeira greve.

Já o ano de 1912 foi marcado por movimentações em torno de outra greve feita pelas mesmas mulheres. Maria Luiza Ugarte Pinheiro destaca que, em 1912, cerca de "56 dessas trabalhadoras declararam-se em greve", ${ }^{62}$ e o estopim teria sido a demissão do gerente por um de seus sócios. Segundo Pinheiro, a imprensa passou a divulgar, com certa estranheza, as notícias sobre essa greve, com receio desse acontecimento se espalhar por outros setores femininos da cidade devido ao contexto sufragista. ${ }^{63}$

Segundo Pinheiro, durante a greve de 1912, o Jornal do Comércio fez alusões "ao movimento sufragista, então em curso nos Estados Unidos, na Europa e também em algumas capitais brasileiras, externando uma posição de franca preocupação e oposição a essas ideias". ${ }^{64}$ O sufragismo recebeu críticas dentro da própria classe trabalhadora em um artigo assinado pelo Centro Operário do Amazonas e publicado pelo Jornal O Construtor Civil, em $1^{\circ}$ de janeiro de 1920. Intitulada A Proletária e o Feminismo, a nota caracterizou alguns pontos que juntos conceituavam o que a autora, Rita Alves da Conceição, entendia como a nova aspiração moderna da mulher, ou apenas "feminismo".

A nota alegava que o voto era uma aberração e um legado do militarismo, que as mulheres tinham coisas mais úteis e nobres a fazer. É interessante verificar como algumas mulheres percebiam essas mudanças por um viés classista, ao destacar que esse "feminismo" seria mais bem aproveitado pela burguesia "que o ócio degenera", apontando diferenças entre as mulheres da classe trabalhadora e as mulheres da classe média.

Deixai legislar sobre a liberdade de votos para a mulher. Essa nova aberração não lhe terá sequer a complacência, tão múltiplos e nobres são seus afazeres para preocupar-se com aquela velharia legada pelo militarismo do qual a

57 PINHEIRO e PINHEIRO, op. cit., p. 160.

58 Ibidem, p. 163.

59 Ibidem, p. 161.

60 Correio do Norte, Manaus, p. 1, 10 ago. 1911.

61 Jornal do Comércio do Amazonas, Manaus, p. 2, 8 ago. 1911.

62 PINHEIRO, Maria Luiza Ugarte. Mulheres portuguesas na belle époque manauara, 1880-1920. In: MENEZES, Lená Medeiros de; SOUZA, Fernando (org.). Brasil - Portugal: pontes sobre o Atlântico, múltiplos olhares sobre a e/imigração. $1^{\text {a }}$ ed. Rio de Janeiro: Eduerj, 2017, v. 1, p. 142.

63 PINHEIRO, op. cit., p. 143.

64 PINHEIRO e PINHEIRO, op. cit., p. 172. 
sociedade moderna governada por trêfegos revolucionários, ainda não se pode desvencilhar. ${ }^{65}$

Dorothy Thompson havia observado que, durante o cartismo, existia uma brecha nas aspirações entre as mulheres que lutavam pela emancipação da classe média e das mulheres trabalhadoras. Aautora destacou que uma das grandes hipocrisias do pensamento conservador era caracterizar a mulher como frágil e delicada, ao mesmo tempo em que explorava outras mulheres em trabalhos degradantes. ${ }^{66}$ Ou seja, para a mulher pobre, o trabalho era colocado como única saída para seu sustento, restando pouco ou quase nenhum tempo para se dedicar a outras pautas, como por exemplo, o sufrágio feminino.

Além dessas problemáticas, as operárias da fábrica enfrentavam outras questões como, por exemplo, os perigos na volta para casa. Por morarem em bairros distantes do centro da cidade, costumeiramente eram alvos de ataques nas ruas. No dia 17 de outubro de 1912, algumas delas enviaram à coluna As queixas do povo, do Jornal do Comércio, reclamações acerca da hora de encerramento das atividades da fábrica: trabalhavam até as 18h30 da noite e ainda precisavam se locomover para suas moradias em bairros distantes. ${ }^{67}$

Contudo, o que diferenciou a greve de 1912 das demais foi o fato de não ser motivada pela extenuante jornada de trabalho ou por conta da insatisfação com os baixos salários, como ocorriam costumeiramente, e sim pelas atitudes tomadas pelos patrões contra os gerentes.

O jornal A Lanceta, em mais uma de suas "brincadeiras", informou sobre a greve de mulheres da fábrica e qual o motivo da paralisação das trabalhadoras. A nota afirmou que elas "não fizeram mais que seu dever" e que "se elas se levantassem por causa de outra mulher é que seria o fato mais extranhável do mundo", ${ }^{68}$ apresentando a visão de que as mulheres rivalizavam entre si, reafirmando os estereótipos de gênero vindos do olhar masculino da imprensa.

O outro jornal, O Chicote, realçou as diferenças entre os homens e as mulheres e apontou que, se para os homens já era complicado, para o sexo feminino era mais complicado ainda lutar por seus direitos, posicionando-se ao lado delas e reafirmando o direito de fazer greve:

Ora, numa crise como a que atravessamos, o homem, que é o sexo forte, luta com as piores dificuldades para a sua manutenção, quanto mais essas pobres criaturas que pertencem ao sexo fraco. Publicando esta notícia, reclamamos o que de direito elas o têm, e ninguém o poderá negar. ${ }^{69}$

Algumas notas de jornal também reconheciam que as mulheres eram exploradas. No entanto, esse posicionamento a favor das greves de mulheres não foi unanimidade entre os

65 Vida Operária, Manaus, p. 2, 9 maio 1920.

66 THOMPSON, Dorothy. Las mujeres y la radicalidad politica en el siglo XIX: una dimension ignorada. Revista Mora: B. Aires, v. 19, n. 2, jul./dez. 2013.

67 Jornal do Comércio do Amazonas, Manaus, p. 3, 17 out. 1912.

68 A Lanceta, Manaus, p. 1, 18 nov. 1912.

69 O Chicote, Manaus, p. 1, 7 dez. 1913. 
trabalhadores masculinos. Muitos acreditavam que as mulheres tomavam seus espaços no mundo do trabalho, enquanto que outros ainda acreditavam que sua presença no mercado de trabalho barateava o preço da mão de obra. Ao reconhecerem que as mulheres tinham direito à greve e que eram exploradas, esses homens - como o redator da notícia - entendiam que elas também faziam parte da classe trabalhadora.

A imprensa manauara descrevia o gerente Tenreiro Júnior com "espírito altruístico e equitativo", alegando que um dos sócios da fábrica o tratava de forma grosseira, um "funcionário probo e trabalhador". ${ }^{70} \mathrm{O}$ caráter "amistoso" do gerente foi colocado em xeque pelo jornal $A$ Lanceta. A nota do jornal afirmava que o gerente "está conseguindo um abaixo assinado, das suas costureirinhas, dizendo que ele é um santo", em tom irônico e finalizando com a expressão "fora satanás!". ${ }^{71}$ Curioso, pois a greve de 1911 se contradizia com a de 1912. Como as operárias podem ter mudado de ideia em apenas um ano? Cabem aqui duas análises.

O gerente da fábrica poderia estar usando sua proximidade com as operárias para ter seu emprego resguardado, o que indicava não necessariamente que elas tinham respeito ou admiração por ele, tendo em vista que a greve do ano anterior havia se dado por conta de suas atitudes.

Pode também ter sido possível que as trabalhadoras tenham utilizado essa greve como mais uma de suas estratégias contra o patronato. Assim, a permanência do gerente teria sido um caminho para manter alguém conhecido no cargo, ao passo que a chegada de um novo gerente poderia acarretar maiores problemas nesse momento em que elas enfrentariam novas paralizações. Maria Luiza Ugarte também fez essas inflexões e questionou o "altruísmo" do gerente. $^{72}$

O que fica claro nesse movimento é que, da mesma forma que as mulheres se movimentaram para manter o gerente em 1912, também o fizeram para criticá-lo um ano antes, mostrando que tinham força política para voltar-se contra um intermediário que não cumprisse com acordos ou negociações.

O gerente ganhou uma matéria no jornal O Chicote, de 1912, com o título Fábrica de Roupas. A nota confirmou, no caso da primeira greve em 1911, que o gerente decidiu que as "pobres criaturas" não tinham o direito de receber o salário integral e deixou de pagá-las no dia correto, lançando assim críticas a Tenreiro, mas se resguardando, pois apesar da crítica, o jornal desejava melhoras à classe proletária.

Esqueceu-se de nós, pois ele sabe que desejamos as melhoras da classe proletária, e não seu desmoronamento. Pois bem, o sr. Gerente entendeu que estas pobres criaturas, que mourejam cotidianamente (e a maior parte delas, coitadas! ... são orfãs de pai e mãe) não tinham direito de receber os seus salários integralmente, deixando de pagá-las no dia de costume. ${ }^{73}$

70 Jornal do Comércio do Amazonas, Manaus, p. 2, 14 nov. 1912.

71 A Lanceta, Manaus, p. 1, 26 out. 1912

72 PINHEIRO e PINHEIRO, op. cit., p. 163.

73 O Chicote, Manaus, p. 1, 7 dez. 1913. 
O gerente Tenreiro Júnior teve sua atuação muito divulgada na imprensa manauara, principalmente pelo Jornal do Comércio. Em janeiro de 1913, mandou convidar a imprensa e demais autoridades para a inauguração da caixa de socorros da fábrica. $\mathrm{O}$ ato foi idealizado pela gerência com a ajuda das 60 operárias do estabelecimento fabril. ${ }^{74}$ Já em 30 de março de 1913, o jornal anunciou que o gerente apresentou algumas peças produzidas pela fábrica no intuito de comparar com produtos produzidos por fábricas na Bahia e pela Fábrica Alliança, do Rio de Janeiro, "não havendo comparação com o que é feito na fábrica Amazonense". ${ }^{75}$ Nesse sentido, "o gerente da fábrica, ao nos mostrar tais artigos, quis demonstrar, com provas evidentes, a superioridade do material empregado na Amazonense, bem como, a diferença notável de preços". ${ }^{76}$

A trajetória de Tenreiro Júnior merece ser estudada de forma mais profunda para que se possa entender como suas redes de sociabilidade influenciaram sua vivência na cidade de Manaus. Foi visto viajando para o Rio de Janeiro em outubro de $1913,{ }^{77}$ e no caminho da capital federal, o paquete Bahia fez uma pausa na cidade de Recife, onde o Pequeno Jornal anunciou que Júnior escrevia as suas impressões de todos os estados que visitava para um periódico na cidade de Manaus. ${ }^{78}$ Em 1915 ele criou, na cidade de Manaus, uma sociedade repatriadora e beneficente chamada Grupo Pró-Póvoa e um jornal chamado O Poveiro, ambos sob a justificativa de ter nascido em Póvoa de Vazim, em Portugal. ${ }^{79}$

Nesse diapasão, as operárias da Fábrica de Roupas Amazonense circulavam por outros ambientes na cidade de Manaus. Em 24 de julho de 1915, as trabalhadoras, junto com grandes segmentos da sociedade, como a colônia cearense e a Universidade Livre de Manaós, fizeram uma campanha em prol das vítimas da fome no Ceará, em virtude das secas que assolavam aquela região. ${ }^{80} \mathrm{Em}$ nota do jornal, as operárias da fábrica fariam um préstito pelas principais ruas do centro da cidade arrecadando mantimentos e dinheiro para a causa. ${ }^{81}$

Em outra ocasião, também participaram dos festejos em homenagem ao aniversário da implantação da república em Portugal, no dia 5 de outubro de 1915. À fábrica, ficou acertado que sua fachada fosse decorada e iluminada à noite, assim como outros estabelecimentos "que içaram o pavilhão português". ${ }^{82}$ Tal informação pode confirmar que, assim como seus donos e o gerente eram portugueses, grande parte das operárias também poderiam ser lusitanas.

Em 1916, a Fábrica de Roupas Amazonense teria um novo dono: o antigo gerente, Tenreiro Júnior. A propaganda veiculada na imprensa referia-se a ela agora como a "Grande

74 Jornal do Comércio do Amazonas, Manaus, p. 2, 18 jan. 1913.

75 Jornal do Comércio do Amazonas, Manaus, p. 7, 30 mar. 1913.

76 Jornal do Comércio do Amazonas, Manaus, p. 7, 30 mar. 1913.

77 Jornal do Comércio do Amazonas, Manaus, p. 5, 28 out. 1913.

78 Pequeno Jornal, Recife, p. 3, 6 nov. 1913.

79 PINHEIRO, Geraldo. Imprensa, política e etnicidade: portugueses letrados na Amazônia (1885-1933). Tese (Doutorado em História) - Universidade do Porto, Porto, 2012, apud: PINHEIRO, Luís Balkar Sá Peixoto e PINHEIRO, Maria Luiza Ugarte, op. cit., 2017, p. 163.

80 Jornal do Comércio do Amazonas, Manaus, p. 2, 24 jul. 1915.

81 Jornal do Comércio do Amazonas, Manaus, p. 1, 26 jul. 1915.

82 Jornal do Comércio do Amazonas, Manaus, p. 2, 6 out. 1915. 
Alfaiataria Tenreiro - Antiga Fábrica de Roupas Amazonense". Acredita-se que essa mudança tenha sido uma estratégia do novo dono para atrair os clientes antigos da fábrica, tendo em vista que nas propagandas divulgadas nos jornais era destacado seu antigo nome. ${ }^{83}$ Júnior divulgou ainda extensas notas na imprensa convidando antigos compradores para fazer visitação e conferir os produtos. ${ }^{84}$

A última informação sobre a fábrica merecedora de destaque foi a nota publicada no Jornal do Comércio em 7 de março de 1917. O informe consistia numa chamada pública onde convidava-se a todas as operárias da fábrica, "não só as antigas como as modernas", para tratar de assuntos de seu interesse. O convite se estendia para familiares e "para todas aquelas que o não tendo feito, o desejem fazer de hoje para o futuro". ${ }^{85}$ Acreditamos que possa se tratar de uma retomada na produção da fábrica, após a troca de dono.

A Fábrica de Roupas Amazonense teve grande destaque nos jornais e foi por conta do alcance das greves na imprensa que as operárias tiveram êxito em grande parte de suas lutas e anseios, ganhando inclusive destaque nas mobilizações do Primeiro de Maio, como será visto adiante.

\section{As operárias, a imprensa e o Primeiro de Maio}

A PRESENÇA FEMININA nos cortejos e mobilizações do Primeiro de Maio foi pouco analisada pela historiografia nacional. Entretanto, na cidade de Manaus as mulheres tiveram suas presenças confirmadas pela imprensa local em pelo menos dois anos: em 1913 e 1914. Nossa contribuição aqui é no sentido de perceber como essas trabalhadoras foram incorporadas nas mobilizações das comemorações e como alguns órgãos da imprensa, majoritariamente masculina, observaram tal participação em um momento de bastante efervescência política e social no cenário local. Destacamos que a intenção aqui não é de esgotar a temática, apenas apresentar mais uma reflexão e enriquecer os debates em torno do Primeiro de Maio.

A primeira evidência da participação feminina nas mobilizações do Primeiro de Maio é do ano de 1905. O Centro Operário da cidade planejava fazer um grande festejo do Dia Trabalhador naquele ano, "pedindo até a cooperação das mulheres que são operárias ou trabalhadoras". O Jornal do Comércio destacou que a direção do centro distribuiu diversas circulares pela cidade fazendo esse pedido. ${ }^{86}$ Não foi possível confirmar se de fato as mulheres participaram daquela mobilização, mas são esses os primeiros indícios de sua participação no Primeiro de Maio.

Foi apenas na década seguinte que essa participação ficou mais efetiva. No $1^{\circ}$ de maio de 1913, as operárias da Fábrica de Roupas Amazonense foram convidadas por estudantes

83 Jornal do Comércio do Amazonas, Manaus, p. 7, 30 dez. 1915.

84 Jornal do Comércio do Amazonas, Manaus, p. 7, 24 mar. 1916.

85 Jornal do Comércio do Amazonas, Manaus, p. 4, 7 mar. 1917.

86 Jornal do Comércio do Amazonas, Manaus, p. 2, 29 abr. 1905. 
universitários da Universidade Livre de Manaós para proferir um discurso às 9 horas da manhã na União Acadêmica. ${ }^{87}$ Esta não foi a única visita das moças, já que, segundo a imprensa, as operárias fariam um grandioso festejo pelo Primeiro de Maio e visitariam as sedes dos jornais que as apoiaram por conta dos movimentos paredistas empreendidos por elas nos últimos três anos. ${ }^{88}$

Sem dúvidas, os movimentos grevistas encabeçados por essas trabalhadoras durante a década de 1910 alçaram-nas à notoriedade no meio operário local. O maior destaque foi entre os trabalhadores que as apoiaram em suas ações, tanto que, como apontado na nota do Jornal do Comércio, as operárias visitaram justamente os locais que Ihes deram suporte durante as greves.

Foi no ano de 1914 que essa participação se deu de forma mais efetiva. Foram mapeados aqui três jornais que cobriram as mobilizações do Primeiro de Maio na cidade, para investigar as posições desses veículos de comunicação frente à participação das mulheres.

É preciso destacar que as representações da imprensa passavam pelo crivo do olhar masculino, carregado de ideologias, significados e intenções. Os conteúdos também assumiam os direcionamentos dos donos e editores dos jornais, de seus colaboradores, jornalistas e escritores, até chegar ao grande público. ${ }^{89}$ No Amazonas, a imagem das mulheres projetadas a partir da imprensa ganhou ares conflituosos e contraditórios, oriundos tanto das "experiências femininas desenvolvidas na região, quanto pelas forças sociais com as quais elas se relacionavam". ${ }^{90}$

Costumeiramente o ritual do Primeiro de Maio seguia uma rotina que se repetia ano após ano desde os idos de 1892 - data da primeira nota sobre o Dia do Trabalhador na cidade $^{91}$-, sendo que em 1914 a mobilização aconteceria de uma forma um pouco diferente. Nesse caso, referimo-nos aos itinerários dos préstitos do Dia do Trabalhador.

Em 1914, a mobilização teve início na praça de São Sebastião, às 16h, com operários das mais diversas oficinas da cidade. Depois de algumas falas, o cortejo partiu da rua José Clemente e parou em frente à sede da Sociedade de Tiro Naval, onde houve mais discursos, e só então a caminhada continuou pela Av. Eduardo Ribeiro. Na sequência, no encontro das ruas Henrique Martins e rua da Instalação, o préstito fez uma pausa na Fábrica de Roupas Amazonense. O ritual seguiu pela rua Municipal, indo até o teatro Alcazar onde encontrou, na praça da Constituição, numerosas pessoas e, por fim, onde se dissolveu a mobilização.

87 Jornal do Comércio do Amazonas, Manaus, p. 2, 30 abr. 1913.

88 Jornal do Comércio do Amazonas, Manaus, p. 2, 30 abr. 1913.

89 LUCA, Tania Regina. A História dos, nos e por meio dos jornais. In: PINSKY, Carla Bassanezi (org.). Fontes Históricas. $2^{a}$ ed., $1^{a}$ reimpressão. São Paulo: Contexto, 2008, p. 139.

90 PINHEIRO, Maria Luiza Ugarte. A mulher na imprensa amazonense, 1900-1950: algumas reflexões. In: XXVII Simpósio Nacional de História - Conhecimento Histórico e Diálogo Social. 2013, Natal/RN. Anais [...]. Natal: Universidade Federal do Rio Grande do Norte, 2013, p. 1-13. Disponível em: http:// www.snh2013.anpuh.org/resources/anais/27/1364739330_ARQUIVO_ArtigoMariaLuizaUgartePinheito AmulhernalmprensaAmazonense.pdf. Acesso em: 28 de março de 2020.

91 Gutenberg, Manaus, p. 1-4, 1 maio 1892. 
Os jornais responsáveis por cobrir a data foram o Jornal do Comércio, A Lucta Social e A Voz do Trabalhador. Com abordagens diferentes, esses periódicos contam de maneira distinta os fatos ocorridos, iluminando alguns personagens e silenciando outros.

Em $1^{\circ}$ de maio de 1914, o prédio da Fábrica de Roupas Amazonense chegou a ser batizado pelo jornal $A$ Lucta Social de "pequena Bastilha", em alusão à Bastilha da Revolução Francesa, que vez ou outra surge como referência nos escritos acerca do Primeiro de Maio em Manaus. Na narrativa do periódico, as operárias da fábrica lançaram flores sobre a passeata que parou em frente ao estabelecimento.

Na sequência, tomou voz "a operária Cecília Miranda que leu um belo discurso o qual hipotecava a solidariedade de sua classe ao operariado irmão em luta e em sacrifícios". ${ }^{22}$ Como destacado, esta não foi a primeira vez que mulheres participaram dos préstitos pelo Dia do Trabalhador na cidade de Manaus, mas possivelmente pode ter sido a primeira vez que elas tiveram voz e certo destaque na imprensa local.

Ainda em frente à fábrica, o acadêmico Euclides Bentes, ao final de sua fala, também prestou homenagens às operárias e convidou-as a seguirem o cortejo pelas ruas do centro, pois "também eram exploradas!". ${ }^{33}$ Mais uma vez, encontram-se evidências de que as trabalhadoras foram reconhecidas como parte integrante do movimento operário, por conta de sua intensa participação no movimento e apoio de militantes como Bentes.

O jornal ainda citou a fala de Tércio de Miranda, que dissertou acerca do Primeiro de Maio, sua história e origem. Logo após, as operárias seguiram a multidão que "desfilava levando na vanguarda o grupo de operárias da fábrica". ${ }^{94}$

A parada simbólica do cortejo em frente à fábrica em homenagem às operárias que haviam organizado e levado adiante diversas greves na cidade foi importante para entendermos a dimensão do que ocorreu naquele momento. O espaço por elas conquistado, adquirindo o direito de fala, foi marcado justamente pela importância das três greves realizadas em 1911, 1912 e 1913, permitindo assim mensurar a relevância e o pioneirismo dessas mulheres nos movimentos paredistas na cidade.

No dia 15 de maio de 1914, o jornal $A$ Voz do Trabalhador, da Confederação Operária Brasileira, também noticiou os acontecimentos ocorridos em Manaus no Primeiro de Maio daquele ano. $\mathrm{O}$ interesse dos redatores de um dos mais importantes periódicos operários do país naquele período levantou alguns questionamentos: qual teria sido o motivo do Primeiro de Maio em Manaus ter sido comentado por um jornal da capital federal? Por que apenas a cidade de Manaus, das regiões Norte/Nordeste, ganhou destaque na publicação?

Um indício pode ser as relações muito próximas que Tércio de Miranda mantinha com A Voz do Trabalhador. Isso ficou perceptível na edição de 15 de maio de 1914, na coluna "Bilhetes e Recados", em que a direção do periódico lamenta a retirada de Tércio de Miranda

92 A Lucta Social, Manaus, p. 4-6, 1 jun. 1914.

93 A Lucta Social, Manaus, p. 4-6, 1 jun. 1914.

94 A Lucta Social, Manaus, p. 4-6, 1 jun. 1914. 
de algo não muito claro na coluna, já que a nota se tratava de uma resposta à solicitação de Miranda. O jornal acatava a decisão da liderança operária de Manaus e o saudava. ${ }^{95}$

Seguindo uma narrativa por vezes muito próxima da que foi divulgada pelo jornal manauara A Lucta Social, o jornal carioca A Voz do Trabalhador, através de Cabesil, seu correspondente em Manaus, construiu uma matéria jornalística bastante interessante e cheia de detalhes. Segundo o jornal, no dia $1^{\circ}$ de maio, por volta das $16 \mathrm{~h}$, havia um número elevado de trabalhadores de diversas sociedades operárias na praça de São Sebastião, local escolhido pelo Comité Primeiro de Maio ${ }^{96}$ para concentração. O que se imagina é que o préstito de 1914 pode ter sido um dos maiores já realizados até então, o que é possível inferir por conta de sua ampla divulgação, tanto na imprensa diária quanto em jornais sindicalistas, tendo inclusive destaque nacional.

Em Do Norte: o $1^{\circ}$ de Maio em Manaus: Imponente Comicio, o correspondente narrou o que mais the chamou a atenção em Manaus. No início, destacou que apesar dos muitos percalços "o Primeiro de Maio teve aqui a sua efeméride grandiosa pelo operariado livre, consciente, altivo e sobranceiro". ${ }^{97}$ Às $16 \mathrm{~h}$, o público já era grande nas redondezas da praça e notava-se um número elevado de acadêmicos da Universidade Livre de Manaós que, segundo o jornal, "aderiram à causa do operariado" de livre vontade.

Primeiramente falou sobre o Primeiro de Maio o estudante Adail Couto, próximo ao monumento Amazonas. Na sequência, discursou o artista gráfico Joaquim Azpilicueta, proferindo longa fala sobre a situação angustiante do operariado de Manaus. A notícia chegou até a transcrever parte da fala de Azpilicueta, que a direcionava aos trabalhadores:

"Ergamo-nos e caminhemos em busca da emancipação; - disse o companheiro - fundemos associações e arrejimentemos à classe trabalhadora e só então poderemos impor-nos a ambição descomunal do patrão, que, além de usufruir todos os lucros que nós produzimos, insiste por não querer pagar em dia os salários do operário". 98

O discurso de Azpilicueta incitava os trabalhadores a criarem e se unirem em torno das associações para só então se revoltarem contra os patrões. Antes de seguirem para a Fábrica de Roupas, o cortejo fez uma parada na Federação Marítima e ouviu o operário José F. Varela. Já na frente da fábrica, falou o acadêmico Euclides Bentes e, na sequência, a operária Maria Cecília de Miranda como representante das outras trabalhadoras. Entretanto, A Voz do Trabalhador, diferente do que fez com os trabalhadores Joaquim Azpilicueta e José Varela, não transcreveu a fala de Cecília, conferindo-Ihe apenas uma frase de elogio: "num belo discurso, no qual interpretava o sentir e a solidariedade da corporação daquela casa industrial". Qual o

95 A Voz do Trabalhador - Órgão da Confederação Operária Brasileira. Rio de Janeiro, p. 4, 15 maio 1914.

96 Foi um comité criado pela União Operária Amazonense durante a década de 1920, que seria responsável pela organização em todos os anos do Primeiro de Maio na cidade, sobretudo na divulgação do que ocorreria durante as mobilizações.

97 A Voz do Trabalhador - Órgão da Confederação Operária Brasileira. Rio de Janeiro, p. 3-4, 15 maio 1914.

98 A Voz do Trabalhador - Órgão da Confederação Operária Brasileira. Rio de Janeiro, p. 3-4, 15 maio 1914. 
motivo da fala da operária não ter sido transcrita em meio a outros discursos masculinos que ganharam destaque?

Isso nos permite inferir que as mulheres, mesmo aparecendo na fonte jornalística, ainda não tinham destaque na hora da transcrição dos fatos e eram colocadas de lado nesses escritos. Mesmo que fosse reconhecido pelo próprio movimento operário que elas "em vista também de serem assalariadas e, portanto, exploradas", e fossem participar do préstito, suas vozes, ainda assim, eram silenciadas.

A matéria destacou na sequência a fala de Tércio de Miranda, que ao fim teria sido "delirantemente aplaudido pelos operários presentes que o ouviam silenciosamente". Já dentro do teatro Alcazar, falou o acadêmico Edgar Castro, libertário, tendo discursado sobre a sociedade futura que os trabalhadores tanto almejavam. Na segunda fala de Tércio de Miranda, no mesmo teatro, percebe-se um grande debate sobre as origens do Primeiro de Maio. Para ele, a data teria surgido no congresso de Chicago como um dia de protesto e não um dia de festa; era necessário que os trabalhadores não confundissem esses dois sentidos do Primeiro de Maio.

No discurso seguinte, Anjelo P. Cabalero destacou que por mais que o capital fosse alçado de forma superior em relação ao trabalho, na verdade, nas relações práticas deveria ser visto como o oposto.

Sem o trabalho o capital não existiria. Colocai - disse P. Cabalero - o capital numa área hermeticamente fechada, e tereis ocasião de verificar como ele é inerte, é improdutivo, sem valor algum. É, pois o trabalho alma-mater do capital e portanto da vida. ${ }^{99}$

É perceptível o teor político da fala de grande parte desses trabalhadores. Na citação anterior, observa-se uma fala de conciliação capital-trabalho de viés socialista, entretanto caracterizando o trabalho como superior ao capital. Tanto o jornal A Lucta Social quanto $A$ Voz do Trabalhador convergem no sentido de um Primeiro de Maio de luta. Alinham-se também no que tange às posições quanto às mulheres: citam, mas não aprofundam sua participação nas mobilizações.

A narrativa do Jornal do Comércio difere um pouco dos acontecimentos do $1^{\circ}$ de maio de 1914 destacados pelos outros periódicos. Enquanto os dois primeiros jornais transcreveram a fala do militante anarquista Tércio de Miranda, o Jornal do Comércio priorizou a fala do gerente Tenreiro Júnior em resposta ao que dissera o acadêmico Euclides Bentes. ${ }^{100}$

O discurso do gerente não foi observado nas outras duas narrativas. Um dos motivos pode ter sido o fator ideológico de cada um dos jornais ou até mesmo de seus editores. O jornal $A$ Lucta Social possuía demanda anarquista e priorizava a divulgação das lutas de trabalhadores e trabalhadoras em prol de melhorias para o dia a dia operário, como explicitado na fala de

99 A Voz do Trabalhador - Órgão da Confederação Operária Brasileira. Rio de Janeiro, p. 3-4, 15 maio 1914. 100 Jornal do Comércio do Amazonas, Manaus, p. 1-2, 3 maio 1914. 
Tércio de Miranda no Primeiro de Maio. No caso do Jornal do Comércio, a proximidade com a elite local ajudava na escolha do que deveria ou não ser publicado, pois era mais interessante deixar nas sombras a fala do anarquista e trazer à luz a fala do gerente, por exemplo. Outro motivo para a fala do gerente não ter sido apontada pelos jornais anarquistas pode ter sido o fato de que o mesmo já possuía seu nome vinculado às greves das operárias e também por Tenreiro Júnior estar alinhado aos donos da fábrica.

As diferenças não param por aí, pois o jornal diário além de não mencionar a fala da operária Cecília de Miranda - que foi noticiada pelos dois jornais operários já citados -, também não se referiu a sua participação, destacando apenas que as trabalhadoras se juntaram ao préstito. Podemos vislumbrar, mais uma vez, que o Jornal do Comércio preferiu silenciar a luta dessas mulheres e ignorar a importância que elas conquistaram para o movimento operário a partir daquele momento. Apesar desse mesmo jornal ter publicado notícias sobre as greves das trabalhadoras, eles ainda questionavam o caráter do movimento comparando com a onda do sufragismo que ocorria pelo mundo, como sendo algo negativo.

$\mathrm{Na}$ busca por informações a respeito da operária Cecília Miranda ou Maria Cecília de Miranda, recorremos mais uma vez à imprensa manauara, onde encontraram-se poucos registros com seu nome. Um deles tratava-se de uma nota de 1915 do Jornal do Comércio, a qual falava sobre uma comissão encarregada de organizar os festejos de Nossa Senhora de Nazaré na Villa Municipal, onde ela era vice-presidente da sociedade. ${ }^{101}$

Um pouco antes, em 1909, encontramos outro registro com o nome de Cecília Miranda. Dessa vez ligada à Sociedade de Tiro Brasileiro. Nesse caso, ela aparece como parte de uma comissão que ofertou uma bandeira bordada por um grupo de senhoras, que seria entregue numa festa em razão da incorporação do grupo na Confederação do Tiro Brasileiro. ${ }^{102}$

Também recorreu-se à imprensa em busca de mais informações sobre as outras funcionárias da Fábrica de Roupas Amazonense que fizeram parte da comissão que lutou pela manutenção de seus empregos. Tais registros não dão certeza de que são as mesmas pessoas, mas ajudam a fazer entender a complexidade de se analisar mulheres na imprensa. Maria Coelho, Posidônia Coelho, Santina de Jesus e Rosa Del Aguila, ainda quando eram funcionárias da fábrica, faziam a interlocução com a imprensa para arrecadar alimentos para a seca no Ceará com ajuda de uma comissão da União Acadêmica. ${ }^{103}$ As outras duas funcionárias Maria da Silva Jatahy e Rosa Lima não tiveram outras informações pertinentes na imprensa.

Destarte, na edição do dia 3 de maio de 1914, o Jornal do Comércio divulgou três imagens referentes às mobilizações do Primeiro de Maio. Em nenhuma delas foi possível observar a presença de mulheres, o que contrasta com o observado aqui até o momento. ${ }^{104}$

101 Jornal do Comércio do Amazonas, Manaus, p. 1, 21 ago. 1915.

102 Jornal do Comércio do Amazonas, Manaus, p. 1, 7 mar. 1909.

103 Jornal do Comércio do Amazonas, Manaus, p. 1, 21 ago. 1915.

104 Jornal do Comércio do Amazonas, Manaus, p. 1-2, 3 maio 1914. 
Esse esquecimento, no entanto, não é por acaso, e tem como resultado a invisibilização da luta das mulheres. Por sorte, utilizando o cruzamento das fontes - imagéticas e escritas - podemos ligar os fios de alguns relatos em que elas apareceram para compreender que estavam lá, ativamente lutando por seus direitos.

\section{Conclusão}

OLHAR O PRIMEIRO DE MAIO pelo viés das relações de gênero permite-nos encontrar e observar a ação das mulheres em um campo que no geral era reservado aos homens. Ou seja, as mulheres trabalhavam, se movimentavam e eram fundamentais no cotidiano da sobrevivência das comunidades de trabalhadores. Por vezes, acabavam sendo colocadas em um fosso e uma grande dimensão do movimento de trabalhadores era ignorada. ${ }^{105}$

No entanto, nem sempre agiam no espaço da greve, do sindicato e nos lugares de visibilidade e liderança do movimento operário - como o Primeiro de Maio. O caso das grevistas da fábrica têxtil ganhou destaque justamente por sua suposta excepcionalidade. Assim, a visibilidade e espaço ocupado também foram elementos de disputa entre os grupos e indivíduos envolvidos com a questão operária - tanto militantes quanto editores e redatores de jornais. Portanto, apenas por conta da participação ativa dessas trabalhadoras nas greves entre 1911 e 1913 é que foi possível sua aproximação mais estreita com as mobilizações do Primeiro de Maio, ganhando destaque na imprensa operária da cidade.

Por fim, constata-se que essas relações são construídas cotidianamente e as aproximações entre homens e mulheres precisam ser mais discutidas, e não apenas quando as mulheres possuem algum protagonismo evidente na luta pela manutenção de seus trabalhos. A construção desses jornais, com presença masculina majoritária, corrobora com a ideia de deixá-las de fora de todo esse processo. Mas elas estavam lá, resistindo e lutando.

Os atores sociais - homens e mulheres, fossem socialistas ou anarquistas - que animavam e participavam das movimentações da data eram diversos e pensavam os caminhos de uma emancipação operária de forma distinta. A cidade de Manaus era palco de suas ambições e lutas que ajudaram a escrever algumas das páginas da história dessa cidade cravada no meio da Floresta Amazônica.

Recebido em: 11/04/2020

Aprovado em: 13/06/2020

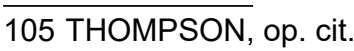

